\title{
FASHION AND THE GOVERNANCE OF KNOWLEDGE IN A TRADITIONAL INDUSTRY: THE CASE OF THE FOOTWEAR SECTORAL INNOVATION SYSTEM IN THE NORTHERN REGION OF PORTUGAL
}

\section{Mário Vale \& Josué Caldeira}

To cite this article: Mário Vale \& Josué Caldeira (2008) FASHION AND THE GOVERNANCE OF KNOWLEDGE IN A TRADITIONAL INDUSTRY: THE CASE OF THE FOOTWEAR SECTORAL INNOVATION SYSTEM IN THE NORTHERN REGION OF PORTUGAL, Economics of Innovation and New Technology, 17:1-2, 61-78, DOI: 10.1080/10438590701279318

To link to this article: https://doi.org/10.1080/10438590701279318

Published online: 10 Jan 2008.

Submit your article to this journal $\sqsubset$

Џ Article views: 177

Citing articles: 4 View citing articles $\longleftarrow$ 


\title{
FASHION AND THE GOVERNANCE OF KNOWLEDGE IN A TRADITIONAL INDUSTRY: THE CASE OF THE FOOTWEAR SECTORAL INNOVATION SYSTEM IN THE NORTHERN REGION OF PORTUGAL
}

\author{
MÁRIO VALE* and JOSUÉ CALDEIRA \\ Centro de Estudos Geográficos, Universidade de Lisboa, Alameda da Universidade, Lisboa 1000K214, \\ Portugal
}

(Received 27 November 2005; Revised 28 February 2006; In final form 17 November 2006)

\begin{abstract}
The paper deals with the footwear industry as a sectoral innovation system. It particularly focuses on the incidental role of fashion in restructuring and innovation within the footwear production. The importance taken by fashion leads towards a more complicated reading of the recent changes of this industry, regarding its organization, innovation processes, and its mode of technological knowledge governance. More especially, within the traditional footwear industry, low levels of knowledge appropriability were combined with low cumulativeness in firms with low-innovative activity. However, as fashion was incorporated in the footwear industry, technological knowledge governance evolves towards higher cumulativeness at least at the industry level. This contribution discusses in detail the pervasiveness of fashion onto the footwear industry. It especially shows how the numerous agents involved in the fashion knowledge production and their geographical concentration allow for increasing returns when they align well with knowledge cumulativeness at the industry level. It also reveals that the renewed knowledge base of fashion exhibits a higher degree of tacitness and typically develops along an external localized knowledge base.
\end{abstract}

Keywords: Fashion industry; Footwear manufacturing; Sectoral innovation system

JEL Classification: $\mathrm{O} 31 ; \mathrm{O} 32$

\section{INTRODUCTION}

In the last two or three decades, the footwear industry in Europe has experienced a process of serious restructuring, which is particularly noticeable in both its geography and technological characteristics of firms. Very often, analyses undertaken on the recent evolution of the sector are driven by a very strong quantitative perspective of these changes. As such, studies emphasize general movements in major sectoral economic variables within countries and across European countries and comparisons with other world regions: production, employment, wages, exports, and imports are thus the focus of the analysis. According to these studies, footwear production is based on a population of SME firms that develop a labour-intensive activity, benefiting from good labour skills often located in less developed regions in Europe - in the traditional centres of footwear production - and in less developed countries in other parts of the world.

\footnotetext{
* Corresponding author. Tel.: +351 217940218; E-mail: mario.vale@ceg.ul.pt
} 
Product innovation occurs mostly as a result of informal processes of learning-by-doing within the firm.

The study of the footwear industry project benefited from the accumulated knowledge of the sector offered by these traditional analyses of the industry; however, the study developed through the perspective of the fashion content would find very strong limits if it would followed a traditional approach of the sector. In fact, the study of the sector through the lens of fashion, that is, through the most important process of restructuring and innovation of the footwear production, leads us towards a more comprehensive and thus complex reading of the recent changes of this industry, regarding its organization, innovation processes, and its mode of technological knowledge governance.

The increasing role of fashion and design activities in the footwear industry is changing very deeply the traditional knowledge base of the industry, which shows an increasing degree of complexity compared with previous stages of footwear production. The perspective of the industry through the lens of fashion also leads us to the study of the crucial linkages among different phases of the production chain of the footwear: conception, production, distribution, marketing, and sales. This was fundamental to the understanding of the complete process of knowledge governance within this industry. It is crucial to comprehend the role of each organization and the complex power relations among the wide range of organizations (enterprises and others) involved in the production of a pair of shoe in order to understand the process of knowledge governance in the industry. This is the reason we ended up taking a perspective of the footwear industry as a sectoral innovation system, which is made of three subsystems: the manufacturing subsystem, the fashion subsystem and the consumption subsystem.

In order to discuss the knowledge generation, accumulation and diffusion in the industry, we organized this paper as follows. Section 2 provides a broad discussion on the fashion issue and its place between consumption and production and an analytical framework regarding the understanding of the fashion process both in terms of cultural and industrial contexts. Section 3 pushes further the issue of the previous Section in terms of understanding the fashion production processes within a truly industrial process involving a broad range of institutions and organizations. As such, it is proposed that the innovation process within fashion industries, particularly in footwear industry, be conceptualized in terms of sectoral innovation systems. In Section 4, we discuss the main findings of our case study developed in the Northern region of Portugal.

\section{THE FASHION ISSUE: ITS PLACE BETWEEN CONSUMPTION AND PRODUCTION}

In the last decades, fashion has increasing its relevance in day-to-day modern social life, extending its influence towards a wide range of industries. Surprisingly, analyses of fashion as a social and economic phenomenon are still scarce. As George Lipovetsky puts it in his insightful work on the history of fashion 'the fashion theme does not shake the intellectual world. The phenomenon must be stressed', states the author, 'while accelerating its legislation, entering new spheres, dragging along with it every social layer and age group, fashion fails to arouse those whose vocation in life is to clarify the functioning and motivations of modern societies'. (Lipovetsky, 1989/1987, p. 15).

In already existing works, the approaches of the fashion issues, rise mainly as an integrated part of consumption processes, as such considered mostly a demand-side phenomena and thus focus on the increasing social relevance of fashion as a result of changing the cultural and 
behavioural patterns of consumers. Thus, the material or economic basis of fashion 'production' has been treated marginally specially regarding its institutional organization, that is, the organization and processes of the industrial production of fashion (Campbell, 1995, p. 109).

Focusing on the footwear industry, a critical analysis of contemporary readings on fashion allows us to identify elements of an alternative approach to the economic and social positioning of fashion within the industry, emphasizing its central role in recent processes of industrial restructuring within the footwear industry.

\subsection{From New Patterns of Consumption Towards an Intensification of the Fashion Processes}

It is acknowledged that during the fordist period, both consumption phenomenon and marketing-related activities played a fundamental role in the functioning of the more developed capitalist economies. For some authors 'Fordism involves a virtuous circle of growth based on mass production and mass consumption' (p. 47). As such,

[c]ommercial capital has a key role in establishing the links between mass production and mass demand via mass advertising, mass retailing (...) consumer research etc. (...) Marketing needs also feed back into design (...) to encourage marginal product differentiation, annual style changes, etc. Thus design becomes a key factor in linking mass production and mass consumption (p. 49) (Jessop, 1992, emphasis added).

However, at that stage of organization of production, as some commentators remind us,

the production apparatus of fordist industries was focus above all on reaping the advantages of economies of scale through the standardisation of products and the cultivation of mass markets. As a result, the cultural content of much output of fordist industry tended to become subservient to the more functional design imperatives (Scott, 1997, p. 326).

The weakening of mass production and the emergence of a flexible accumulation regime from which reveals a direct confrontation with the rigidities of fordism, resting upon 'flexibility with respect to labour processes, labour markets, products, and patterns of consumption' (Harvey, 1990, Part II, p. 147), brings about significant changes in the organization and functioning of consumption processes, from which arises an ever-wider diversity of consumption patterns, thus breaking the iron rule of mass consumption of standardized products.

As such, fashion phenomena approaches are still focused on changes of cultural surroundings as well as the psychological changes displayed by consumers. 'Identity' and 'lifestyle' are the major buzzwords that have influenced the majority of readings on the recent changes of consumption practices "whose demands are no longer regulated by "an economy of needs" but by "an economy of desire and dreams", or the longing for something new and inexperienced' (Gronow, 1997, p. 74). As Lipovetsky holds, the strength of fashion is a corollary of the power of the 'self' and 'the advent of a society, fully restructured by seduction, the ephemeral and the logic of fashion, itself' (p. 19). The powerful appealing of the New becomes an 'autonomous cultural demand' (p. 38), which emerges as the backdrop of fashion process (Lipovetsky, 1989/1987).

However, as we will discuss later, it is particularly arguable to suggest an intensification of the fashion phenomenon through a social and psychological process, resulting from the democratic changes of modern Western societies, without considering the linkages of fashion processes and material production, thus approaching fashion as an actual industry or as a particular industrial cluster. After all what is at stake here, we would emphasize, is the complex base of institutional, organizational, and market structures, which constitute the governance mode of the fashion processes. 


\subsection{From Personality Affirmation to the 'Cultural Materialization of the Economic' and Then to the Institutional Complex of Fashion Production}

One might assume that there is little doubt about the increasing importance of fashion regarding its influence on consumption patterns and practices as well as industrial strategies at least as far as buyers-driven production ${ }^{1}$ is concerned. After all, fashion, as some observers claim 'is functional to the economic system of capitalism. Fashion is (...) an ideal and extreme case of waste, by transforming otherwise perfectly useful (in the narrow functional sense of the word) objects into totally useless ones (in the aesthetic sense). As such, without doubt, it promotes sales and accelerates the turnover of capital' (Gronow, 1997, p. 104), which is particularly welcome in industries under increasing international competition such as footwear production.

However, there have been major changes in the process of fashion production changing the role of fashion within industrial production systems (Crewe, 1996; Vervaeke and Lefebvre, 2002). Some readings emphasize the increasing rapidity and regularity of novel goods production, which would be a specific feature of the fashion process of the present times (fashion becomes mass fashion in a mass consumption society) (Gronow, 1997, p. 82). Undoubtedly, the pressure for speeding up innovation and shortening creativity cycles has been higher than ever, which brings with it major changes in industrial organization and corporate competitive strategies. However, as far as fashion phenomenon is concerned we might suggest that the novelty goes far beyond the speed and regularity. These changes are better understood within the context of the increasing complexity of the relationship between culture and economy. It is recognized that capitalism 'is moving into a phase in which the cultural forms and meanings of its outputs become critical if not dominating elements of productive strategy' (Scott, 1997, p. 323). In fact, there has been strong claims regarding an emerging new dialectic of culture and economy (Sayer, 1997). Lash and Urry, in their influential 'Economies of Signs and Space' attempts to summarize the new culture-economy relationship under the notion of 'reflexive accumulation' process, by which they stress four relevant aspects of contemporary capitalism: (a) the extent to which socio-economies are currently based on services, (b) the extent to which information-intensive research and development processes has succeeded a material labour process, (c) the extent to which social and social-cultural processes enter as importantly in the moment of consumption as they do in that of production, and finally, (d) the extent to which culture has penetrated the economy itself (Lash and Urry, 1994, pp. 60-61). The two latter issues are particularly relevant to the central debate of this paper. We have seen over the last decades a serious development of industrial activities that in one way or another are related to the production of goods and services which marketable qualities are based on aesthetics or semiotics attributes. Lash and Urry named such process as the aestheticization of material objects. 'Such aestheticization [they write] is instantiated, for example, in production, in which (...) the design component comprises an increasing component of the value of goods, while the labour process as such is less important in its contribution to value-added' (Lash and Urry, 1994, pp. 34, 4). Addressing this issue, Crang and Malbon put forward a well accurate formulation, as they conceive the new culture emphasis of production as the 'cultural materialization of the economic' through which 'the cultural does not just surround or rework economic imperatives [as] it is part of them' (Crang and Malbon, 1996, p. 709).

We have just arrived, thus, at a point where fashion - for sure the industrial activity that by its intrinsic nature produce nothing else than aesthetics and symbolic components of material

\footnotetext{
${ }^{1}$ We borrow this definition from Gerreffi (1994), concerning his study of global commodity chains. To Gereffi, buyer-driven commodity chains refer to those industries in which large retailers, brand-named merchandisers and trading companies play the pivotal role in setting up decentralized production networks (p. 97). On the other hand, profits in buyer-driven chains derive from unique combination of high-value research, design, sales, marketing, and financial services (p. 99).
} 
products - is understood as something more than an output of a 'social logic' emerging from a kind of 'novelties seeking fever'. There are, in fact, more than psychological and cultural processes working over aesthetics. We need, thus to understand the material base, this is the institutional and industrial complex that lay behind the increasing relevance of fashion within production systems.

\section{THE STUDY OF FASHION IN THE FOOTWEAR INDUSTRY AS SECTORAL INNOVATION SYSTEM}

Fashion is a decisive element in the product differentiation of the footwear industry. The increasing fashion content in the footwear industry confirms the relevance of the creative activity in this sector. In this Section, the existing relationship between firms behaviour and the organization and the technological environment in the footwear industry is explored. We aim to understand the learning processes of agents involved in the production of shoes with a certain content of creativity and how the combination of technology and creativity to produce something new is managed.

\subsection{The Governance of Knowledge in the Footwear Industry}

The production of footwear with a strong fashion-content goods can be considered as an activity where a specific mode of governance of technological knowledge plays a key role. Fashion production can also be understood as a collective good where knowledge is the result of a complex process of creation of new information building upon the mix of competencies acquired by means of learning processes, the socialization of experience, the recombination of available information and formal R\&D activities (Antonelli, 1999, p. 245). We are, however, in the face of a new mix of industrial competencies regarding the generation of new products. Some authors emphasize the symbol-processing activities as the fundamental characteristic of the creative aspect in industries with a strong design component (Lash and Urry, 1994, p. 112). Therefore, footwear producers have to manage a distinctive and dedicated flow of interactions regarding its internal structure and its productive environment, requiring a specific ability to organize, control, and combine different resources (Antonelli, 2001).

The production of footwear may not be compared with other industries where innovation activities are dependent on R\&D equipment and instrumentation. In a study of sectoral patterns of technical change by Pavitt (1984), the footwear industry is considered as a supplierdominated activity, although in many ways it can be classified in the production-intensive sectors, as the author recognized. Along with other traditional manufacturing sectors, firms in the footwear industry are in general small and have poor in-house R\&D and engineering capabilities. Accordingly, 'they appropriate less on the basis of a technological advantage, than of professional skills, aesthetic design, trademarks and advertising' (p. 356). Moreover, technological development is direct mainly to process innovation and is highly dependent on suppliers from other sectors.

The opportunity conditions in the footwear industry are based on the external sources of knowledge to the industry and do not match the opportunity level of emergent industries. Malerba and Orsenigo (1993) refer to the depletion of technological opportunities along with the industry life cycle. Considering the footwear industry a mature activity, firms develop technological strategies oriented to incremental innovations or imitation rather than radical innovation strategies. One of the most relevant changes has been the increasing content of fashion in the product, enabling product differentiation and an higher value added. However, stylist innovations alter the configuration of humdrum resources employed in the footwear 
industry. Traditionally, tanning and chemical industries as well as the footwear components industry had a strong relevance in the product innovation. The footwear production with intense fashion content was at the beginning reserved to products for luxury market segment. The entry of new specialized firms in the industry was made possible by the new knowledge base used in the production of fashionable leather goods.

The increasing role of fashion in the footwear industry opened up opportunities for innovation in established producers. Literally, fashion is used in almost all the footwear segments, and therefore new agents arrived at the industry with new knowledge. Established firms had to cope with this changing knowledge base, and the learning processes require interaction with the new fashion agents. The stylists and designers know current and past styles and inspired themselves on fine arts, literature and social happenings that can be translated into new designs (Caves, 2000). However, they cannot be absolutely sure about the products that will be bought. Nevertheless, new knowledge is based on previous bits of knowledge, which confirms the cumulativeness of fashion knowledge, in the sense that '... today innovations and innovative activities form the base and the building blocks of tomorrow innovations' (Malerba and Orsenigo, 1993, p. 48). Thus, present innovative firms in this activity are more likely to be the innovative firms in the future.

In the traditional footwear industry, low opportunity and low appropriability are combined with low cumulativeness in the firms with no innovative activity. However, when fashion is incorporated in the footwear industry, it seems that cumulativeness is present at industry level rather than firm level. The numerous agents involved in the fashion knowledge production and the geographical agglomeration of fashion agents denote increasing returns that align well with cumulativeness at industry level. It also reveals that knowledge base on fashion has an high degree of tacitness, typically an external localized knowledge base. The high degree of complexity is much more related with the different competences necessary to the production process, and frequently external to the manufacturing firms' boundaries, ranging from fashion trends definition to components production, to consumer tastes analysis and to distribution. Obviously, the tanning industry, the R\&D institutions, and the manufacturing equipments industry are also essential competences to produce leather products with a fashion content.

The cumulativeness at industry level goes along with low appropriability conditions, which means that knowledge diffuses across firms of the footwear industry. However, firms make use of different instruments or means to protect their innovations. As it is known, patents, secrecy, continuous innovation, and the control of complementary assets are the means used by firms to protect innovation. In the case of fashion, all these instruments are used by firms; however, secrecy and continuous innovations are more used than other means due to the creative factor of fashion production. The need to change at least two times a year the footwear collection requires a permanent innovation at the industry and firm levels. Nevertheless, innovative firms do not show the new products until the pre-market phase, thus avoiding imitation strategies from other competitors. After this phase, innovative firms develop other new products to the next season (continuous innovation strategy). Some firms are able also to create a brand or patenting innovations, which represent a strategy of protecting innovations through different means. The brand and patenting strategies are not concerned exclusively with fashion knowledge; on the contrary, they are often related with product attributes and material physical properties.

To summarize, in the footwear industry both opportunities for innovation and appropriability are lower than other industrial sectors; however, there is high cumulativeness at industry level. Based on Malerba and Orsenigo, footwear producers usually develop two strategies to respond to the changes in the knowledge base: obtain complementary assets and strengthen the core competences. In the next Section, we attempt to map the agents and functions in the entire footwear industry considering the changing knowledge base in this sector. 


\subsection{The Footwear Sectoral Innovation System}

The introduction of fashion in the footwear industry is a response to consumer's changing behaviour and to the competition of producers from low-wage countries outside Europe. However, the introduction of fashion in the footwear production changed the knowledge base at industry level, and thus the governance forms of knowledge are rather different from the past. In fact, we argue that new agents and institutions play a central role in the footwear industry, which makes a quite big difference to the sector if we put changes in a sectoral innovation system perspective.

Drawing from the national innovation systems literature, the sectoral innovation system, as well as the technological and regional innovation systems, relates in a systemic perspective the production structure and the institutional level (Lundvall and Maskell, 2000). According to the authors, the virtues of such an approach can be summarized as follows: innovation has to do with stable relationships and close interaction with external agents; these relationships and interactions between the agents also are non-market type; context (national) offer different possibilities to establish organized markets.

The footwear sectoral innovation system can be developed considering three subsystems: the fashion, the manufacturing, and the consumption subsystems, which are interlinked through technological and symbolic communication channels. The key agents of this innovation system are represented, illustrating the diversity and complexity of the footwear agents in a broad perspective (Fig. 1).

The manufacturing subsystem clearly dominates before the increasing role of fashion in the footwear business. In fact, productivity gains were achieved through equipment modernization and the introduction of information technologies in the production phase and also in the product conception. These changes meant an increasing technological loss of control by footwear firms, since innovations are to be found in other sectors that are then incorporated in the footwear industry. Nevertheless, leather and components suppliers still have a very important role in the industry, especially the last ones, since fashion content is heavily dependent on

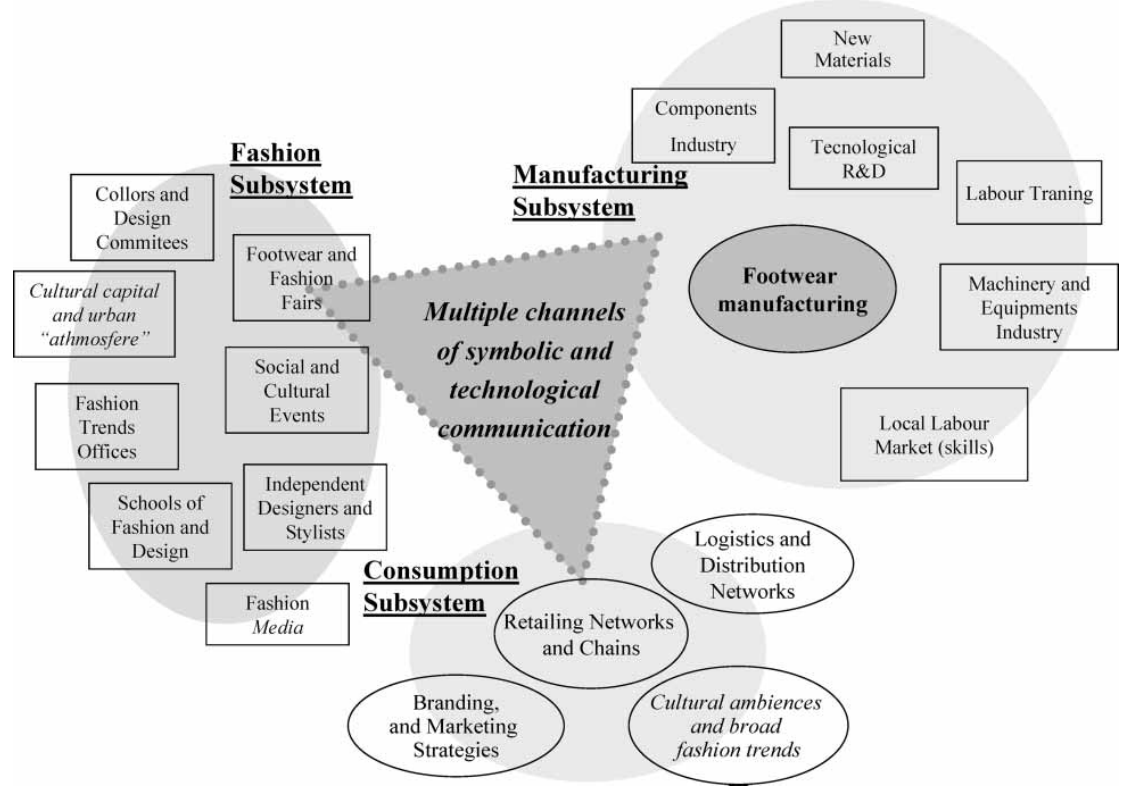

FIGURE 1 Footwear sectoral innovation system. 
components innovations. Local labour markets make available the necessary skills to the industry and are central to flexible production. Larger- and medium-sized firms regularly keep on subcontracting and build large networks and, occasionally, subcontract home family work. Often traditional footwear firms are delimited by the boundaries of this subsystem and do not establish relevant links with other parts of the footwear sectoral innovation system.

The fashion subsystem consists of several agents with different functions, such as colours and shape committees, schools of fashion and design, fashion trends offices, designers and stylists, fashion media, and fashion events. As footwear fashion is deeply related with clothing and garment fashion and to a certain extent with the general fashion trends, some powerful organizations identify the future fashion trends in domains like colours, shape, and materials. A footwear producer needs to capture these trends in advanced to develop its own shoe collection, requiring a governance structure to incorporate this knowledge at the firm level. Despite that, fashion-related firms entered the footwear market with a certain degree of success with new products under specific brands, even if they need to subcontract all the production, i.e. it is possible to approach the market with success having no industrial capacity. The traditional footwear producer has to compete with those firms in the market and to enter the complex fashion world as a way to respond to the rapid changes in consumer preferences.

Finally, the consumption subsystem is composed of different material assets like retailing networks and mega stores, distribution and logistics, and immaterial assets like brand and labels. As we mentioned above, the control of complementary assets is a viable innovative strategy to firms in traditional industries in order to increase appropriability. Large footwear producers often control distribution networks and introduced successful brands in the market. As in the previous subsystem, distribution firms entered the market and created their own brands and labels, using the very same subcontracting strategy for the brand case or buying part of a collection from a footwear producer and market it with their own label.

The interactions in an innovation system are critical for its performance. The communication channels are fundamental to the knowledge generation, accumulation, and diffusion in the footwear sectoral innovation system. The principal communication channels in this innovation system are the inter-firm relationships, the science, technological, and educational system, the local labour market, the international fairs and other commercial events, and the fashion magazines and media. The multiple channels of symbolic and technological communication are complex, and firms approach the knowledge governance structure in different ways (assuming the introduction of fashion as a major change in the knowledge base of footwear production), as it is shown in next Section.

\section{THE FOOTWEAR SECTORAL INNOVATION SYSTEM IN THE NORTH REGION (PORTUGAL)}

\subsection{The Footwear Industry in the North Region (Portugal) in the European Context}

Europe forms one of the main areas of footwear production in the world. As far as the European Union (EU) is concerned, it stands out as the main source of the world's production in this sector, reaching, in value, almost $44 \%$ of the world's production (and only $13 \%$ of the world's number of pairs). Among the manufacturing industries, the footwear industry contributes with only $0.6 \%$ to the total production of European manufacture (Eurostat - ProdCom). However, in several southern European regions, the footwear industry is a fundamental part of the local economy. Italy has a predominant position as the biggest producer and European leader in the sector, contributing with $\sim 43 \%$ of the 15 member States' production. Together with Spain, Portugal, and France, production reaches $\sim 83 \%$ of the total sector production (volume) in the EU. 
Important changes in the world geography of the footwear sector have recently been identified. The main characteristic of these recent alterations comes from a reinforcement of South East Asian countries' share of world market, particularly regarding the volume of production (number of pairs). At the beginning of the last decade, a profound change in the external trade relations of the sector took place, as the European Commission observes 'the European footwear industry's share of EU market has fallen (from around 50\% in preceding years to $45 \%$ in 1999) because of the constant rise in imports' (C.E.C., 2001, p. 7).

These changes have had dramatic impacts in Southern European traditional footwear producing regions, from which the northern region of Portugal is an example (Fonseca et al., 2001; Melo and Duarte, 2001; Vale and Caldeira, 2007). This region is responsible for more than $90 \%$ of the total employment, firms, and turnover of the industry in Portugal.

\subsection{Case Study Methodology}

From the start, we considered that, given the nature of the study, research that privileged quantitative research methods would only offer very limited results in understanding the theme in hand. We were interested in the comprehension of the influence of fashion on the models of firm organization and the relation between shoe producers and the various industrial activities involved in the conception and production of the shoe. Thus, an intensive research approach was adopted based primarily on qualitative data collection and analysis.

This collection of interviews seek to, on the one hand, exhaustively identify the components of the functional organization and, on the other hand, understand the most important connection channels, established between the diverse functions, in a perspective of the governance of knowledge and innovation.

We opted for a non-random method of sample definition of firms to study, using a procedure for constructing a convenience sample (Fink, 1995). In this sense, we asked the organizations interviewed in the first phase of the research to list the firms where fashion was held as a structural factor of the production process and the position of the firm in the market. The list of firms presented by the various organizations was not, in fact, very long. We selected eight footwear producer firms as well as several institutions related with the sector (training, technology transfer centres, trade union, entrepreneurs association, fashion agents, and so on). The approach taken with these selected firms and institutions was developed in a second phase of the study and consisted of a semi-structured face-to-face interview. The interviews followed a list of topics to be discussed, which organized the conduction of the interview around five thematic areas:

- general characterization of the firm/institution;

- industrial organization and firms' (institution) relation with consumer market;

- forms of management of technological knowledge;

- the firms' (institution) relation with fashion;

- the firms' (institution) relation with its local environment.

\subsection{The Sample and Characteristics of the Firms Studied}

Firms can be divided into three firms' size categories: three firms having less than 100 employees, three firms having between 100 and 500 employees, and the last two firms fitting into the class of large or very large firms, with over 500 employees (Tab. I). The diversity of the sampled firms is evident both in terms of production volume (pairs produced annually per firm/establishment) and in terms of sales volume. However, as will be seen ahead, and what 
TABLE I Selected features of studied firms.

\begin{tabular}{lccccc}
\hline Firms/establishments & Created/established in & $\begin{array}{c}\text { Capital } \\
\text { nationality }\end{array}$ & $\begin{array}{c}\text { Number of } \\
\text { workers }\end{array}$ & $\begin{array}{c}\text { Turnover } \\
\text { (.000 EUROS) }\end{array}$ & $\begin{array}{c}\text { Pairs per year } \\
\text { (0.000 Pairs) }\end{array}$ \\
\hline Aerosoles Group & 1987 & Portuguese & 700 & 65,000 & 2500 \\
Eccolet Portugal & 1984 & Danish & 1300 & 64,000 & 2500 \\
Kyaia & 1984 & Portuguese & 300 & 37,000 & 650 \\
Campor & 1955 & Portuguese & 400 & 9340 & 250 \\
J. Sampaio \& Irmão & 1980 & Portuguese & 100 & 5650 & 70 \\
Everest & 1942 & Portuguese & 70 & 3000 & 200 \\
Calzeus & 1994 & Portuguese & 85 & 10,000 & \\
Mr-Estudos P. Calçado & 1990 & Portuguese & 50 & 3000 & \\
\hline
\end{tabular}

Source: Fieldwork undertaken by the authors in 2002 and 2003.

will be an interesting result of this research, there is not a direct relation between employment, sales and production (pairs), and patterns of behaviour towards fashion.

The sample is composed of firms created in three distinct periods: two firms are over 50 years old, which have industrial structures along the same lines of with the 'traditional' firm course of the Portuguese shoe sector, being small-/medium-sized, geared at mass production and exportation, and subcontracted by big brands or large shoe producers. Four of the firms were created during the 1980s, during a period where business strategies were already determined by the new configuration of the European economic space resulting from an increasing process of economic integration. The two remaining firms were created during the 1990s and, certainly not by chance, constitute the most extreme examples of firms situated in very marginal niches of the fashion-footwear market.

The sample also puts into evidence the presence of diversified industrial structures. Firms with a more elementary organizational structure only possess one establishment, created by an ex-worker of the footwear sector and with a very simple command hierarchy (some being family based). Yet, the sample also includes firms with a highly developed organization of the production process extended to the distribution, marketing, and commercialization phases. In this last group are included the firms with ample subcontracting networks, already extending to the South East Asia and Eastern European countries, handling, in some cases, their very own distribution and retail networks (Tab. II).

\subsection{Fashion and the Diverse Patterns of Knowledge Governance in the Footwear Industry}

In order to follow with the footwear sectoral innovation system's conceptual framework, three dimensions of analysis were considered: business and technological strategy (production volumes, consumer markets, firms competitiveness, control of production technologies, and firm's history); business structure and productive organization (establishments and the division of work between establishments, relationship with suppliers, and mode of connection to the consumption subsystem); fashion process (degrees of incorporation of the fashion factor in the final product, internal structures of fashion, process of conception of new productions, and modes of communication with the consumers).

The relevant information collected supports the identification of three patterns of knowledge governance, as a result of the perspective taken through the fashion lens in our analysis, considered a determinant element of the innovation process in the footwear industry. A first pattern reveals a non-complex business organization showing a weak performance in the creation process; this pattern is named as imitative and dependent production (pattern I). The second pattern refers to a business organization whose distinctive feature is its focus on 
TABLE II Overall features of studied firms.

\begin{tabular}{|c|c|c|c|c|c|c|c|c|c|c|c|c|}
\hline $\begin{array}{l}\text { Firms/ } \\
\text { establishment }\end{array}$ & $\begin{array}{l}\text { Created/ } \\
\text { established } \\
\quad \text { in }\end{array}$ & $\begin{array}{c}\text { Capital } \\
\text { nationality }\end{array}$ & $\begin{array}{l}\text { Number } \\
\text { of } \\
\text { workers }\end{array}$ & $\begin{array}{c}\text { Turnover } \\
\text { (O.OOO } \\
\text { EUROS) }\end{array}$ & $\begin{array}{l}\text { Pairs } \\
\text { per year } \\
(0.000 \\
\text { pairs })\end{array}$ & $\underline{\text { Multiest }}$ & $\begin{array}{c}\text { ablishment? } \\
\text { Other } \\
\text { production } \\
\text { places }\end{array}$ & $\begin{array}{l}\text { subcontracting } \\
\text { places }\end{array}$ & $\begin{array}{l}\text { Subcontracted } \\
\text { by other } \\
\text { firms? }\end{array}$ & $\begin{array}{l}\text { Does the } \\
\text { firm own a } \\
\text { retail chain? }\end{array}$ & Branding & $\begin{array}{l}\text { Design and } \\
\text { conception } \\
\text { function }\end{array}$ \\
\hline $\begin{array}{l}\text { Aerosoles } \\
\text { Group }\end{array}$ & 1987 & Portuguese & 700 & 65,000 & 2500 & Yes & $\begin{array}{l}\text { Portugal } \\
\text { Italy }\end{array}$ & $\begin{array}{l}\text { Portugal } \\
\text { Ukraine } \\
\text { Poland } \\
\text { Vietnam }\end{array}$ & No & Yes & Own brand & $\begin{array}{l}\text { Design Office in } \\
\text { Italy }\end{array}$ \\
\hline $\begin{array}{l}\text { Eccolet- } \\
\quad \text { Portugal }\end{array}$ & 1984 & Danish & 1300 & 64,000 & 2500 & Yes & $\begin{array}{l}\text { Denmark } \\
\text { Holland } \\
\text { Slovakia } \\
\text { Cyprus } \\
\text { Thailand } \\
\text { Indonesia }\end{array}$ & $\begin{array}{l}\text { No } \\
\text { subcontracting }\end{array}$ & No & Yes & Own brand & $\begin{array}{l}\text { Design Centre in } \\
\text { Denmark }\end{array}$ \\
\hline Kyaia & 1984 & Portuguese & 300 & 37,000 & & Yes & Portugal & $\begin{array}{l}\text { China } \\
\text { Vietnam } \\
\text { Taiwan } \\
\text { Romania }\end{array}$ & Yes & $\begin{array}{l}\text { No, but they } \\
\text { have powerful } \\
\text { distribution } \\
\text { networks }\end{array}$ & $\begin{array}{l}\text { Own brand and } \\
\text { others producers } \\
\text { brand }\end{array}$ & $\begin{array}{l}\text { External } \\
\quad \text { designers }\end{array}$ \\
\hline Campor & 1955 & Portuguese & 400 & 9340 & 650 & No & & Local & Yes & No & $\begin{array}{l}\text { Own brand (weak) } \\
\text { and retailers label }\end{array}$ & Modellers \\
\hline $\begin{array}{l}\text { J. Sampaio \& } \\
\text { Irmão }\end{array}$ & 1980 & Portuguese & 100 & 5650 & 250 & No & & Local & Yes & No & $\begin{array}{l}\text { Own brand (weak), } \\
\text { retailers label, } \\
\text { and others } \\
\text { international } \\
\text { brands }\end{array}$ & Modellers \\
\hline Everest & 1942 & Portuguese & 70 & 3000 & 70 & No & & Local & Yes & No & $\begin{array}{l}\text { Own brand (weak) } \\
\text { and retailers label }\end{array}$ & Modellers \\
\hline Calzeus & 1994 & Portuguese & 85 & 10,000 & 200 & No & & Local & No & Yes & Own brand & $\begin{array}{l}\text { Designer (the } \\
\text { owner) }\end{array}$ \\
\hline $\begin{array}{l}\text { MR-Estudos P. } \\
\text { Calçado }\end{array}$ & 1990 & Portuguese & 50 & 3000 & & No & & Local & No & No & Own brand & $\begin{array}{l}\text { Designer (the } \\
\text { owner) }\end{array}$ \\
\hline
\end{tabular}

Source: Fieldwork undertaken by the authors in 2002 and 2003. 
market niches whose consumption patterns follows a strong symbolic contents. This is the pattern of production for market niches (pattern II). The third pattern regards the most complex business organizations and whose distinguishing feature is a high control of the entire industrial chain of shoe production. This pattern is classified as overall control of the production chain $(\text { pattern III) })^{2}$.

\subsubsection{Knowledge Governance Pattern I: Imitative and Dependent Production}

The fundamental characteristic in this pattern of knowledge governance is the high control of techniques and technologies at the production phase, thus guaranteeing a high quality product resulting from technological knowledge accumulated during the firms' life. Firms better characterized by this pattern are old firms ( $\sim 50$ years old). Besides the quality of production, its business strategy is, on the one hand, to assure a great capacity to respond (on time) to the orders of the various clients and, on the other hand, to guarantee flexibility of production in order to respond to orders with varying sizes. These firms also present a good capacity of conception and development of the product, although revealing great difficulty in affirming themselves in the non-industrial phases of the productive process (namely, conception and retail) (Fig. 2). For this reason, these firms are highly dependent on orders from other firms in the sector, allocating part of its production to contracts established with other firms in a subcontract regime. Their main clients are, on the one hand, shoe firms with a brand and, on the other hand, medium-sized, retail networks to whom shoes with the respective shops' private label are sold. As they have no control over the phases of commercialization, this pattern of knowledge governance shows a significant transferral of (economic) value to the client firm.

In organizational terms, this type of corporate organization is represented by firms with a single establishment, medium-sized (200 employees), presenting a very simple organic structure, with few hierarchies and weak specialization outside the production phase, where the organization of work is marked by its versatility. In regard to corporate networks, the shoe production firm establishes with other local firms, fundamentally family based firms, subcontracting relations, namely for the cutting and sewing operations, characterized by intense and unskilled labour. The relationship of the firm with suppliers, namely component suppliers (hides and soles), constitute important sources of information in technological terms, thus important in the process of industrial innovation.

In regard to product conception, the firm-type of this knowledge governance pattern presents a very elementary organic structure of conception and product definition. The degree of specialization and 'professionalization' is actually rather low, as the entire creation process depends, on the one hand, on the owner's opinions, and on the other hand, on the information collected by sellers from customers and, finally, from information collected through gathering information about the competing producers and from market leaders. The basic information that supports the process of shoe creation is, in this type of firms, generated outside the firm, either by leading firms or by sources of information about the tendencies in footwear and components.

In summary, this pattern of governance of innovation and technological knowledge includes firms whose position in the footwear sectoral innovation system is characterized by a strong concentration of know-how in the manufacturing subsystem and with few connections or competencies in the other subsystems, i.e. the fashion sub-system and the consumption subsystem.

\footnotetext{
${ }^{2}$ In another article, the authors addressed the issue of geographical proximity vs. distant networking on the knowledge governance of these firms (cf. Vale and Caldeira, 2007).
} 


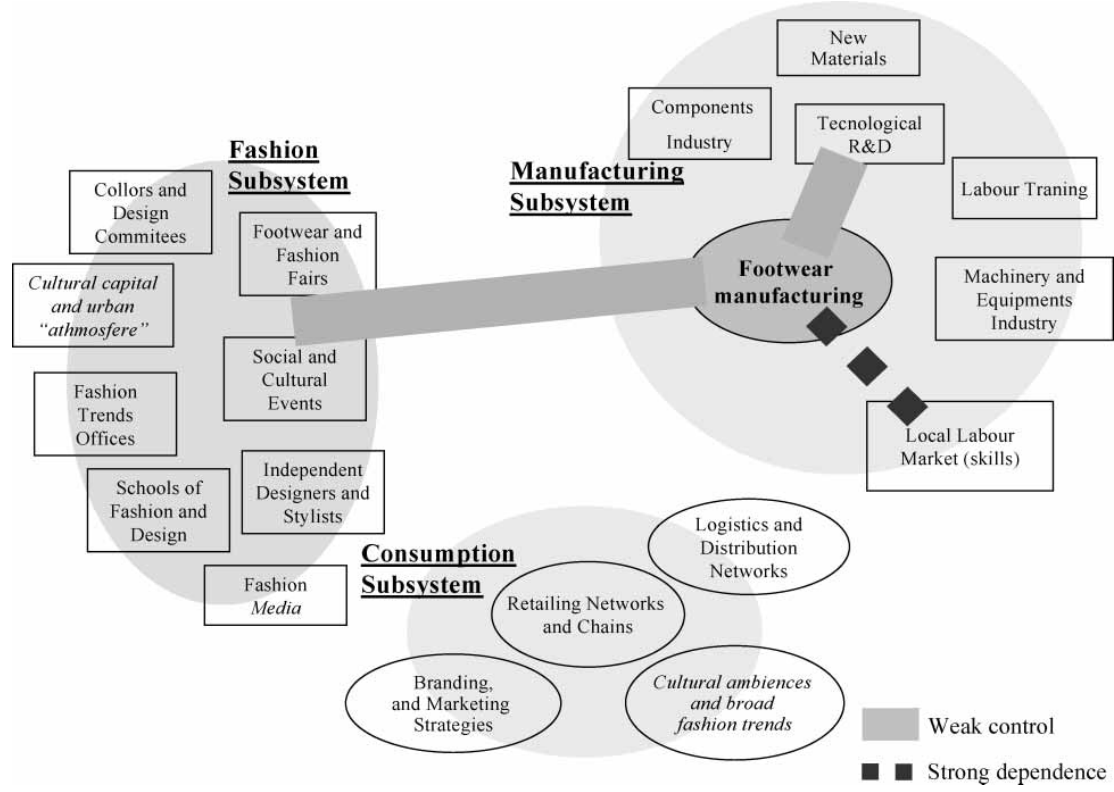

FIGURE 2 Knowledge governance pattern I: imitative and dependent production.

\subsubsection{Knowledge Governance Pattern II: Production for Market Niches}

The pattern of knowledge governance in firms orientated towards market niches is distinctive in terms of the importance that is attributed to the characteristics of cultural and consumption patterns of certain groups of consumers (Fig. 3). The price of a pair of shoes is significantly higher than the average price. However, we are not referring to a production segment orientated towards the so-called radical fashion, where consumption patterns are (exclusively) determined by the aesthetic and symbolic characteristics of goods. The firms that are included here are rather recent, small-sized, run by a design specialist whose production is geared at groups of consumers with high-quality patterns and fashion followers. Thus, the firm's strategy follows the production of footwear with high aesthetic contents and high patterns of production quality. The scale of orders is generally small and very small, and, just as in the previous pattern, flexibility of production is a fundamental factor in the firm's operation. The high levels of automation and computerization of production are also accompanied by high levels of management computerization, namely in production planning, in order to respond to the needs created by the simultaneous production of a high number of shoe models.

In regard to their industrial and technological structure, this pattern of governance is characterized by firms with a single industrial establishment, also a small retail network. The selling points are located in central areas in European capital cities (as well as outside of Europe) marked by an intense cultural and fashion environment in order to value the marketing strategy and the firm's brand. Thus, these firms have an integrated and global approach to the production and commercialization chain. Due to the technological and material needs, we note in this type of firms a more intense and rich relation with suppliers, be it component or equipment suppliers, namely for the adaptation of machinery for specific needs (this happens most frequently with production planning and management support equipment). In relation to labour, we observed that a great part of employment regards the phases of production and product management, customer management, as well as conception and distribution. 


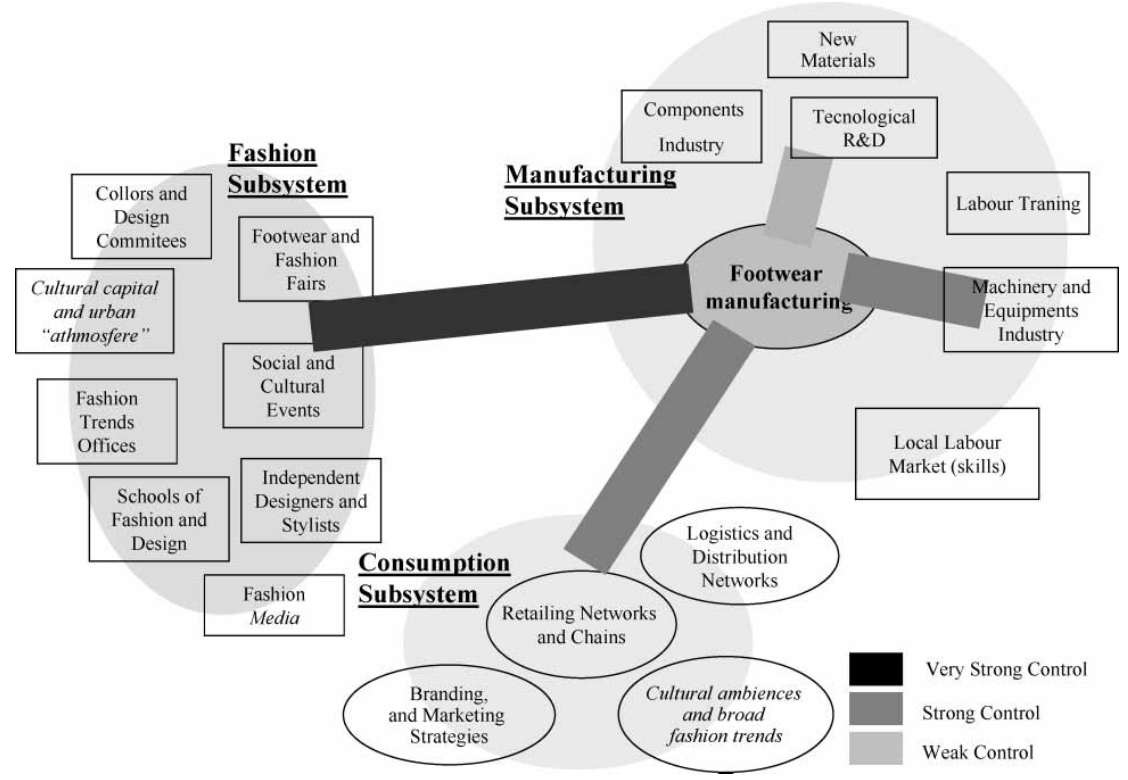

FIGURE 3 Knowledge governance pattern II: production for niche markets.

The firm owns a brand that, although limited to the market niche, detains a critical role in the marketing strategy ensued. The creative capacity of the firm derives from the entrepreneur, who is frequently a stylist with renowned conception qualities. Processes of monitoring fashion trends are particularly developed and with it relations with component suppliers as well as the owner's contacts and external relations. In this sense, associations with other foreign stylists that collaborate in the definition of new models are frequently verified.

In sum, firms following this pattern of knowledge governance have a strong aesthetic content directed at a particular niche of consumers. This characteristic determines the firm's entire organization and activity within and outside of production phases. The connection to the consumption subsystem is strong, both through marketing strategies and through the type and location of retailing shops owned. However, they are a type of business organization characterized by low-production volumes. They are, in fact, small shoe firms.

\subsubsection{Knowledge Governance Pattern III: Overall Control of Value Chain}

The pattern of knowledge governance classified as overall control of value chain is observed in the most complete and complex forms of production organization (Fig. 4). One first characteristic regards the economic and business dimension. Here, the large dimension commands: i.e. high volumes of production, high volumes of direct and indirect employment, ample subcontracting networks, and vast commercialization networks. The business strategy is based on the control of the entire production and value chain and, particularly, by a strong, direct presence in crucial phases of the production chain. This strategy is followed in order to avoid, as much as possible, the transferral of value outside the firm and guarantee greater stability in running the firm. Due to the diversity of the firms' functions, its scale in terms of production, and the geographical amplitude of the firms' activities, a fundamental critical factor in this typology is the ability to connect, integrate, and coordinate the entire value production chain: conception, production, distribution, retail, and consumption monitoring. The firms in this pattern present 


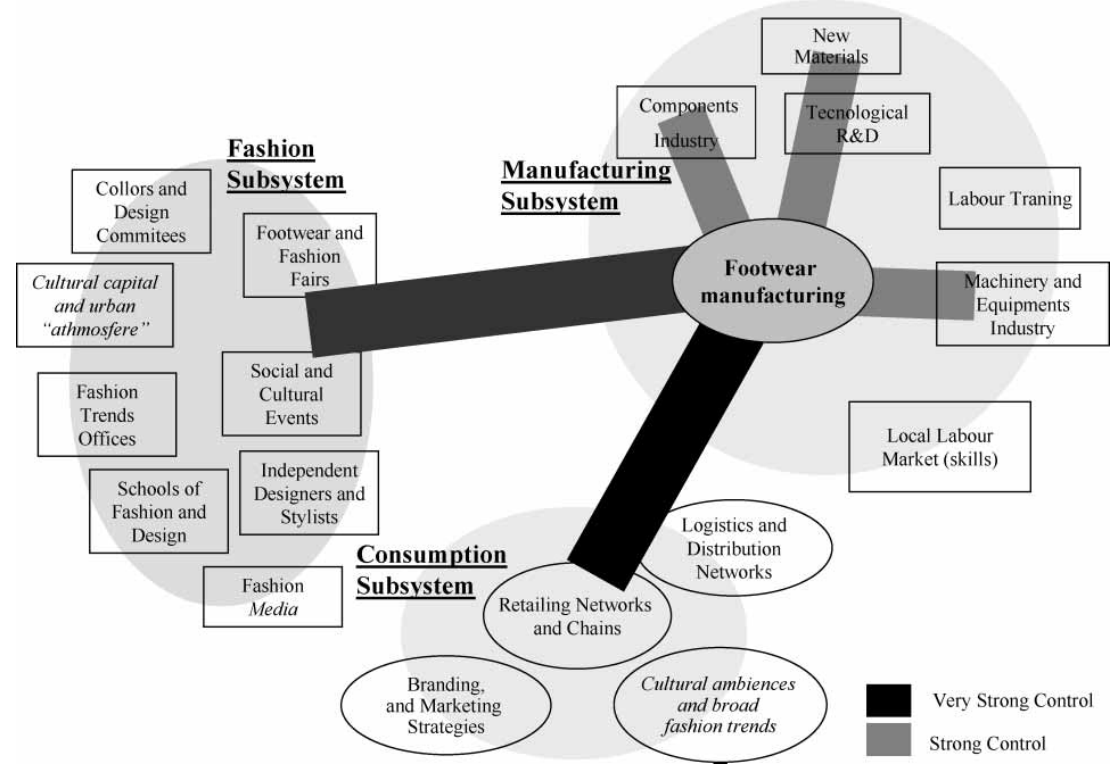

FIGURE 4 Knowledge governance pattern III: overall control of value chain.

a very strong position in the phases of conception, branding, and retail, but simultaneously have a strong industrial structure destined at direct production. They operate, namely, in the crucial phases of shoe production, i.e. in the assembly and finishing phase.

Another fundamental attribute of these firms is the importance of branding. They own strong brands, with international reaching, sometimes global reaching, constituting the structural factor of connection with consumers sustained in the integrated marketing strategy.

The brand, and the entire symbolic environment around it, emerges as the form of protecting firms from the low levels of appropriability associated with shoe production. With a brand, revenue is, on the one hand, generated from the manipulation of the consumption and creation of a protected space in the footwear market. On the other hand, the strength of the brand allows the increase of value transfers deriving from subcontracted firms that frequently work exclusively dependent on the orders made by branded firms.

The vertical quasi-integration of production - from conception to retail - is the distinctive element of this pattern in relation to its industrial organization. The establishments have high functional specialization. On the other hand, this industrial organization presents a high level of internationalization, following a profoundly hierarchical spatial production structure, both in technological terms and in regard to work processes. There is, in fact, a distinctive geographical division of labour within industrial organization. Firms control wide subcontracting networks. These networks amplify the international nature of the organization of production and strength the hierarchical character of the spatial organization of production. As in the other cases, subcontracting here also regards the more labour-intensive and less-demanding (technologically and in terms of qualifications) production phases. The power relations between firms are thus profoundly asymmetrical, in favour of the leading firm.

The industrial organization of this type of firm extends to the component production industries: namely, hides and soles whether through the setting up of new establishments or through strategic alliances with firms or institutions. These latter relationships are more balanced in terms of power relations. 
In regard to the process of product conception, it is based on a rather structured and systematic way. Fashion departments count on enormous specialization and endowed with a vast group of specialists - stylists and designers. Quite frequently, fashion departments are located in European cities with an intense creative environment and high symbolic capital. These are also places where proximity with component firms allows for the establishment of communication channels rich in technological knowledge regarding fashion trends. These firms frequently assume themselves as market leaders and trend makers, thus becoming references to competing firms.

In summary, the type of firms characterized by this pattern of knowledge governance distinguish themselves by the high control they have on the entire shoe-productive cycle, accomplished through the high rates of vertical integration of production or through strategic associations. Although operating in the phase of shoe production, it is, however, in the phases of conception and retailing and, particularly, in the development of branding that the firm centres its strategic activity. The form and capacity of coordination of this vast production chain is thus a fundamental element of governance of knowledge in this type of firm.

\section{CONCLUSION: THE CHANGING NATURE OF A TRADITIONAL INDUSTRY}

The footwear industry has undergone an intense process of increasing complexity in terms of industrial organization leading towards a new structure of the knowledge base of the industry. There is an ongoing process of getting away from the traditional features of the industry, which previous competitive factors were based on relatively cheap semi-skilled and skilled labour reproducing strong localized tacit knowledge resources. In fact, the tradition is changing in the footwear industry.

The perspective to better understand these changes comprehensively was through the lens of fashion content, given its increasing role in the broad performance of the industry. As fashion assumes a critical role in innovation processes, it has led to significant changes in industrial organization, adding greater complexity to the traditional processes of industrial innovation. This is critical to our findings: fashion content is now a kind of particular knowledge (or a specific input) that, at a specific point of the production process, enters into the production of a pair of shoes; instead fashion is better understood as a process that has gained wide space in the organization of the industry. It has changed not only the way footwear industry is organized but consequently changed the structure of power within the industry. Through the increasing fashion content in the production of footwear, new nodes of industrial control have emerged. It is this process of power restructuring within the industry that is leading towards new arrangements of the industrial knowledge base. As such, new modes of knowledge governance have developed.

Fashion dramatically speeded up innovation processes and shortened innovation cycles. In this way the management of time became a critical issue in the market performance of firms. On the other hand, the competencies of time control of the entire production-distribution process emerged as 'a strategic variable to be deployed as a competitive weapon, and in this manifestation it directly affects how the production system operates' (Schoenberger, 1994) and particularly, we would add, it directly affects how the governance of technological knowledge is achieved.

The knowledge base of the footwear industry clearly involves inputs and activities behind the boundaries of the traditional manufacturing firm. We extended our analysis towards the organization of the consumption and also towards the generation of fashion itself. In terms of functional organization of the industry, we proposed a footwear sectoral innovation system based on three subsystems: manufacturing, consumption, and fashion. In terms of knowledge 
governance as well as in terms of the functioning of the industry what is fundamental is to understand the circuits and flows of technological knowledge connecting resources, skills, and competencies in the industry. The interactions and the communication channels are fundamental to the knowledge generation, accumulation, and diffusion both at firm and industry level.

In this way the (false) tacit-codified division (Johnson et al., 2002) appeared as an limited analytic tool to comprehend the recent evolution of the industry. We emphasize that the footwear industry has become much more systemic and complex in terms of knowledge base. We found that the literature on sectoral innovations systems as an appropriate perspective regarding the study of the late changes in footwear industry.

The increasing complexity of the systemic form of the knowledge base of the industry raises important questions regarding the knowledge coordination at the firm level. The evidence from our case studies suggest the critical role of firm competencies, what some authors call the metastructure that allows combining the necessarily different structures of the various bits of tacit and codified knowledge (Malerba and Orsenigo, 2000). The development of such competencies are translated, namely, into the firm's dominance of new innovation sources and availability of new product development structures, holding different characteristics from those firms in sectors whose scientific knowledge base is determinant. Although there is no one best way to perform the fashion factor in the industry, it seems clear that producers in the footwear innovation system usually develop strategies to respond to changes in the knowledge base, namely, through the control of complementary assets and increasing core competences.

\section{Acknowledgements}

The authors are grateful to all members of research project TELL - Technological Knowledge and Localised Learning: What Perspectives for a European Policy? (HPSE-CT2001-00051), which provide the appropriate atmosphere to carry out this research.

\section{References}

Antonelli, C. (1999) The Evolution of the Industrial Organisation of the Production of Knowledge. Cambridge Journal of Economics, 23, 243-260.

Antonelli, C. (2001) The Microeconomics of Technological Systems, New-York: Oxford University Press.

C.E.C. (2001) Report on the Promotion of the Competitiveness and Employment in the European Footwear Industry, Brussels, Commission of the European Communities.

Campbell, C. (1995) The Sociology of Consumption. In Miller, P. (ed.) Acknowledging Consumption: a Review of Studies. London: Routledge.

Caves, R. (2000) Creative Industries. Contracts between Art and Commerce. Cambridge: Harvard University Press.

Crang, P. and Malbon, B. (1996) Consuming Geographies: a Review Essay. Transactions of the Institute of British Geographers, 21, 704-719.

Crewe, L. (1996) Material Culture: Embedded Firms, Organisational Networks and the Local Economic Development of a Fashion Quarter. Regional Studies, 30, 257-272.

Fink, A. (1995) How to Sample in Surveys. London: Sage.

Fonseca, P.M., Lameira, S. and Beleza, V. (2001) Curtumes, Calçado e Marroquinaria em Portugal. Lisboa: INOFOR. Gereffi, G. (1994) The Organization of Buyer-Driven Global Commodity Chains: How U.S. Retailers Shape Overseas Production Networks. In Gereffi, G. and Korzeniewicz, M. (eds.) Commodity Chains and Global Capitalism. Westport: Praeger.

Gronow, J. (1997) The Sociology of Taste. London: Routledge.

Harvey, D. (1990) The Condition of Post-Modernity. Oxford: Basil Blackwell.

Jessop, B. (1992) Fordism and Post-Fordism: A Critical Reformulation. In Storper, M. and Scott, A. (eds.) Pathways to Industrialisation and Regional Development. London: Routledge.

Johnson, B. et al. (2002) Why All This Fuss about Codified and Tacit Knowledge. Industrial and Corporate Change, 11(2), 245-262.

Lash, S. and Urry, J. (1994) Economies of Signs and Space. London: Sage.

Lipovetsky, G. (1989/1987) O Império do Efémero. Lisboa: Publicações Dom Quixote. 
Lundvall, B.A. and Maskell, P. (2000) Nation States and Economic Development: From National Systems of Production to National Systems of Knowledge Creation and Learning. In Clark, G.L., Feldman, M.P. and Gertler, M. (eds.) The Oxford Handbook of Economic Geography. New York: Oxford University Press.

Malerba, F. and Orsenigo, L. (1993) Technological Regimes and Firm Behavior. Industrial and Corporate Change, 2(1), 45-71.

Malerba, F. and Orsenigo, L. (2000) Knowledge, Innovative Activities and Industrial Evolution. Industrial and Corporate Change, 9(2), 289-314.

Melo, M. and Duarte, T. (2001) O calçado em Portugal. Uma análise da competitividade. Lisboa: GEPE.

Pavitt, K. (1984) Sectoral Patterns of Technical Change: Towards a Taxonomy and a Theory. Research Policy, 13(6), 343-373.

Sayer, A. (1997) The Dialectic of Culture and Economy. In Lee, R. and Wills, J. (eds.) Geographies of Economy. London: Arnold.

Schoenberger, E. (1994) Competition, Time, and Space in Industrial Change. In Gereffi, G. and Korzeniewicz, M. (eds.) Commodity Chains and Global Capitalism. Westport: Praeger.

Scott, A. (1997) The Cultural Economy of Cities. International Journal of Urban and Regional Research, 21(2) 323-339.

Vale, M. and Caldeira, J. (2007) Proximity and Knowledge Governance in Localized Production Systems: The Footwear Industry in the North Region of Portugal, European Planning Studies, 15(4), 531-548.

Vervaeke, M. and Lefebvre, B. (2002) Design Trades and Inter-Firm Relationships in the Nord-Pas de Calais Textile Industry, Regional Studies, 36(6), 661-673. 